This item was submitted to Loughborough's Research Repository by the author.

Items in Figshare are protected by copyright, with all rights reserved, unless otherwise indicated.

\title{
Away from prying eyes? The urban geographies of 'adult entertainment'
}

PLEASE CITE THE PUBLISHED VERSION

PUBLISHER

(C) Sage Publications

VERSION

AM (Accepted Manuscript)

LICENCE

CC BY-NC-ND 4.0

\section{REPOSITORY RECORD}

Hubbard, Phil, Roger Matthews, Jane Scoular, and Laura Agustin. 2019. "Away from Prying Eyes? the Urban Geographies of 'adult Entertainment". figshare. https://hdl.handle.net/2134/4407. 
This item was submitted to Loughborough's Institutional Repository (https://dspace.lboro.ac.uk/) by the author and is made available under the following Creative Commons Licence conditions.

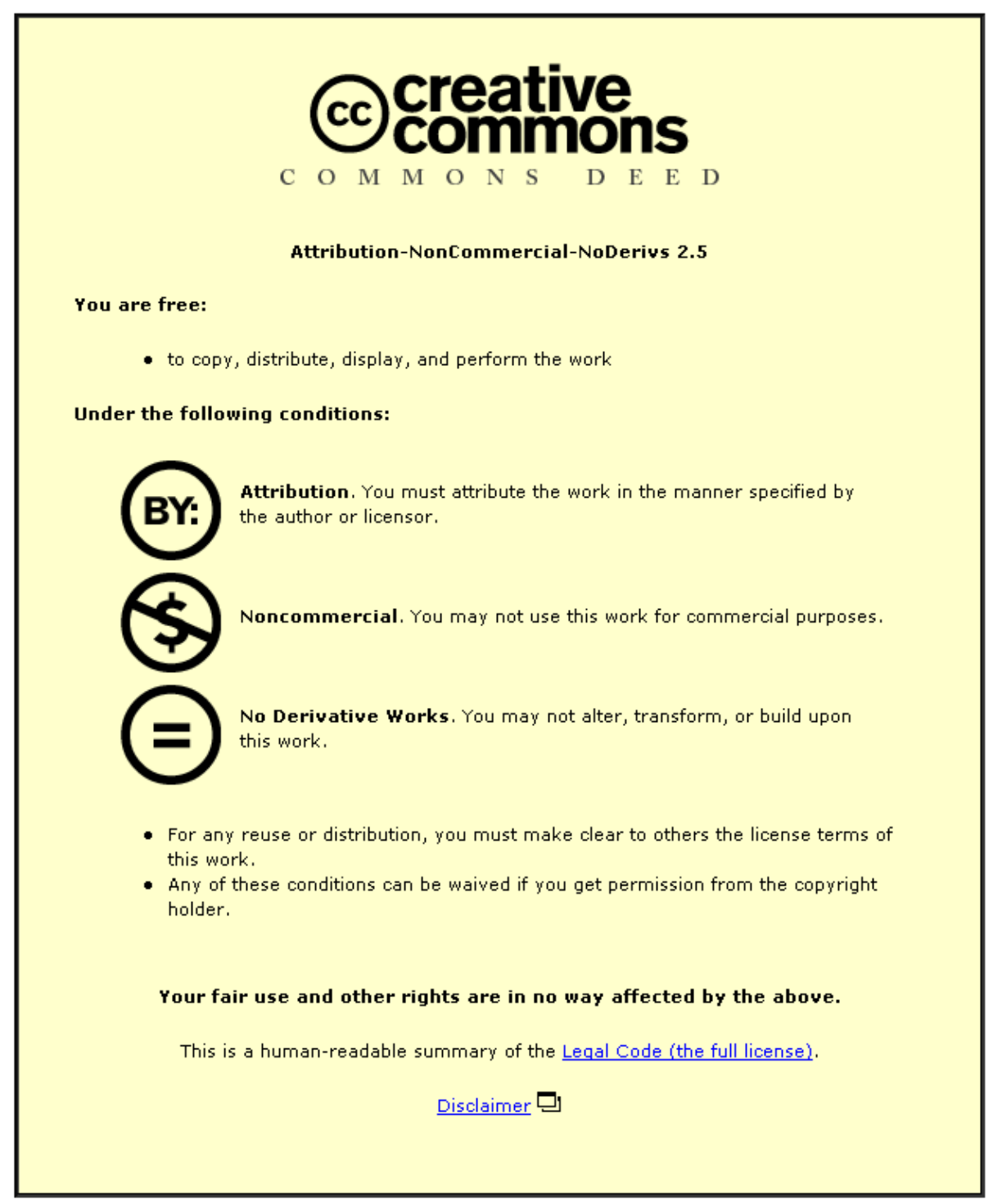

For the full text of this licence, please go to: http://creativecommons.org/licenses/by-nc-nd/2.5/ 


\title{
Away from prying eyes? The urban geographies of 'adult entertainment' Phil Hubbard, Roger Matthews, Jane Scoular and Laura Agustín
}

\begin{abstract}
Most towns and cities in the UK and US possess a number of venues offering sexually-oriented entertainment in the form of exotic dance, striptease or lap dancing. Traditionally subject to moral and legal censure, the majority of these sex-related businesses have tended to be situated in marginal urban spaces. As such, their increasing visibility in more mainstream spaces of urban nightlife raises important questions about the sexual and gender geographies that characterise the contemporary city. In this paper we accordingly locate the phenomena of adult entertainment at the convergence of geographic debates concerning the evening economy, urban gentrification and the gendered consumption of urban space. We conclude that these sites are worthy of investigation not only in and of themselves, but because their shifting location reveals much about the forms of heterosexuality and homosociality normalised in the contemporary city.
\end{abstract}

\section{INTRODUCTION}

Once considered prurient about sexual and bodily matters, geographers are now acknowledged as having developed distinctive and incisive accounts of the role of place, space and environment in the constitution of sexual identities. Feeding off a diverse range of

queer scholarship, geographers' distinctive take on the relations of sexuality and space was first manifest in studies of gay and lesbian residence; latterly, however, geographers have also scrutinized spaces generally regarded as heterosexual, exploring how hegemonic sexual values are spatially inscribed (Cowens 2003; Thomas 2004). One prominent theme in this literature has been the mapping of commercial sex work (Hart 1995; Hubbard 2000; Tani 2002). Nonetheless - as in the wider social sciences - the majority of geographical work on commercial sex fixates on street prostitution. This preoccupation is not surprising given it raises important questions about the limits of public space, but this focus appears somewhat shortsighted given the majority of sexual goods and services are now sold off-street in 'bars, restaurants, cabarets, clubs, brothels, discotheques, saunas, massage parlours, sex shops with private booths, hotels, flats, dungeons for bondage and domination, and cinemas' (Agustin 
2005, 620; see also Harcourt and Donovan 2005; Matthews 2005; Weitzer 2005). Moreover, information and communication technologies have increasingly allowed for the selling of virtual sex, with Zook (2003) arguing the pervasive geography of the Internet is allowing new groups of consumers to purchase sexual services at a distance.

The fact commercial sexual services are bought and sold across a range of virtual and real spaces suggests that geographers' gaze, so often drawn towards spaces of street prostitution, might beneficially be directed towards the wider range of sites of commercial sex. Developing this argument, this paper argues increasing attention needs to be devoted to sexrelated businesses, defined here as venues which trade on the promise of sexual gratification (see Adult Working Group 2006). While this definition might conceivably include massage parlours, brothels and flats where prostitution occurs, in this paper we concentrate on venues such as lap-dancing clubs, striptease joints, sex cinemas and adult cabarets where sexually-provocative representations, displays or performances are central to the nature of the business (Bott 2006). While such venues have a long precedent, with some commentators suggesting the burlesque theatres of the 1920s and 1930s represented the apogee of adult entertainment (Liepe-Levinson 2003) in this paper we suggest they are making an increasingly significant contribution to the entertainment economy. Yet our key argument in this paper is that such sites demand to be taken seriously by geographers not simply because they represent important spaces of sexual commerce but because their location and visibility within the urban landscape is highly revealing of the sexual values that dominate in particular contexts.

As such - and not withstanding the fact sex-related businesses exist in suburban and some rural locales - in this paper we locate these sites within debates surrounding the sexual geographies of Western cities (particularly those in the UK and US). In the first section of the paper we accordingly note the traditional association made between sex-related businesses and notions of sexual danger that has encouraged the state and the law to enact forms of spatial confinement, surveillance and exclusion intended to limit such businesses to marginal urban locations (if, indeed, they are tolerated at all). In this light, the recent tendency for some marginalised and even criminalised forms of business to be re-inscribed as legitimate sites of 'adult entertainment', and to take their place alongside 'mainstream' 
spaces of leisure and entertainment is nothing short of remarkable. As such, in the second part of our paper we explore this putative mainstreaming of sex-related businesses, suggesting the increased tolerance of venues is as much related to the emphasis put on the night-time economy by policy-makers as it is to changing sexual mores.

Given sex-related businesses are now increasingly central to the leisure economy of many Western cities, in the third section of our paper we note the relevance of accounts drawing attention to the corporate gentrification of city centres, and the concomitant displacement of activities deemed to disturb the carefully-cultivated ambience of leisured consumption. Our argument here is that the increasing centrality of sex-related businesses within urban 'playscapes' is suggestive of the privileging of particular forms of corporate investment. Developing this argument, and noting that sex-related businesses accommodate only a limited range of sexual and gender identities, in the final part of the paper we seek to emphasize the gendered dimensions of this process (not least the association between spaces of adult entertainment and corporate homosociality). Our key conclusion, therefore, is that the contemporary regulation of adult entertainment may be normalising specific forms of homosociality and heterosexualty by ensuring certain forms of adult entertainment are accessible and visible in the urban landscape, while others remain hidden or marginalised.

\section{MARGINALISING THE 'OBSCENE': THE EXCLUSION OF SEX-RELATED BUSINESSES}

Histories of sexuality suggest the presentation of the naked body as an object of sexual gratification has always excited considerable social debate, with the state and law often seeking to regulate 'live' sexual entertainment (striptease, burlesque, peep shows) or pornographic media (magazines, videos, books) to protect those individuals who might be 'most easily' corrupted (Barcan 2004; Mason 2005). In relation to this, it has often been middle-class men who have legislated against and censored the 'obscene', arguing it is not them, but women, children and the 'uncivilised' classes they are seeking to protect (Hunter et al 1993; Leonard 2005). This was explicit in mid-Victorian period, when the 1857 Obscene Publications Act was used to enact the seizure of books and prints on the basis they might 
'deprave and corrupt those whose minds are open to such immoral influence' - particularly working-class women (Nead 1997; Sigel 2003). Though scarcely pornographic by today's standards, late Victorian tableaux vivant and living statuary was likewise opposed by members of the National Vigilance Association and other moral purity organizations concerned with the corrupting effects the sight of scantily-clad women might have on audiences. An additional concern here was that the women posing in these performances needed to be 'saved' before they committed other immoral acts. In both respects, campaigners were concerned with the potential for the semi-naked body to sexually arouse, and for such performances to encourage prostitution (Assael 2006). This lead to the censorship of theatrical and music hall performances by municipal authorities determined to demonstrate their commitment to moral improvement by sanctioning artistically-merited nudity but prohibiting the lewd and suggestive (see also Walkowitz 2005).

Likewise, in the early years of the twentieth century, female burlesque dancing in the US was depicted by civic, religious and moral reformers as inflaming working class passions, propelling working men to seek adulterous liaisons, abandon their families, and jeopardize their workplace productivity (Ross and Greenwell 2005). Friedman (2000), for example, reviews the decade-long campaign against burlesque entertainment waged in New York by religious, anti-vice, and municipal activists in the 1930s, lead by mayor Fiorello LaGuardia. Initially obscenity trials were used to censor the content of burlesque striptease, yet the fact that striptease artistes wore flesh-coloured underwear meant that it was difficult for opponents to substantiate allegations of explicit sexuality. As such, Property Owner Associations, concerned burlesque shows were lowering the tone of particular neighbourhoods, pressurised New York's licensing commissioner not to renew burlesque venues' licenses on the basis of their clientele, not the performance per se, alleging that threatening crowds of men would congregate on the streets outside theatres, harassing female passers-by. Friedman hence argues the eradication of burlesque in New York was by underpinned by anxieties about the disorderliness of the male working-class audience: by 1942, every burlesque theatre license in New York had been revoked on the grounds they were the habitats of 'sex-crazed perverts' (cited in Friedman 2000, 87). In other contexts, however, different concerns were to the fore; in San Francisco, for example, transvestism within burlesque revues prompted fears that performances were encouraging homosexuality 
(Boyd 2003).

However, attempts to repress sexual entertainment and commerce through outright prohibition or censorship have often proved futile. Sides' (2006) account of the post-war transformation of San Francisco's Tenderloin district demonstrates this by highlighting the cat-and-mouse games played as owners of premises sought to work around the controls imposed by the Division of Liquor Control - and later the Alcoholic Beverage Control Board - to prevent activities 'injurious to public morals'. For example, a series of 'topless trials' in the late 1960 s preceded the introduction of minimum clothing rules in licensed venues, with dancers forced to wear skin-coloured 'pasties'; however, this was short-lived, with the California Supreme Court ruling in 1968 that naked dancing did not violate standards of community decency. The subsequent spread of (naked) exotic dance venues through the Tenderloin and North Beach area was to provoke considerable anxiety, with over 5000 protestors participating in a Take Back the Night march in 1978. Under pressure from both women's groups and the powerful Hotel Employers Association, the adult business zoning laws introduced by Mayor Feinstein in the late 1970s prevented the seemingly inexorable rise of peep shows and naked dancing venues - though many entrepreneurs simply transformed their premises into X-rated video-rental outlets (Sides 2006).

In this sense, while authorities have sometimes sought to prohibit the opening of sex-related businesses within their jurisdiction, the impossibility of preventing pornography circulating in society means a more normal response has been to instigate a 'politics of concealment' (Kendrick 1996, 35). One dimension of this is the state and law's attempts to limit sexuallysuggestive performances to specific urban spaces which are not evidentially not part of the public realm (i.e. are not accessible to minors) but which are accessible to adults (whether freely or by way of payment). In turn, marking such sites off as potentially disordered or transgressive enables the state and law to unquestioningly identify sex-related businesses as deserving of regulation, allowing them to pragmatically limit the visibility of such businesses so that they do not impinge on the lives of those who do not want to participate in sexual commerce. Through this politics of concealment, the state upholds the liberal principle that adults have the right to consume sexual performances and materials, yet maintains its insistence that obscenity threatens public (urban) order if it becomes publicly or freely 
available (Leonard 2005).

This politics of concealment has an obvious spatial corollary in the strategic isolation of sexrelated businesses in locations where they excite least opposition. Ryder (2004) thus highlights the role of civic leaders and urban governments in pushing such businesses away from residential and 'family' spaces and toward industrial districts through a variety of 'command-and-control' techniques (i.e. licensing, zoning and planning powers) used. The majority of US cities, for example, have used zoning restrictions since the 1970s to prevent 'adult business' from opening in particular neighbourhoods or operating within the vicinity of residences, schools and religious facilities, characteristically pushing adult businesses towards the fringes of cities (Tucker 1997). Furthermore, in most instances, zoning ordinances now seek to prevent the co-location of sexually-oriented businesses, with many US city ordinances prohibiting such businesses within 1000 feet of one another (Kelly and Cooper, 2000). US courts have tended to uphold such zoning ordinances on the (disputed) basis that sex-related businesses may attract anti-social elements and promote neighbourhood deterioration (Hudson 1997; Fisher et al 2004), allowing municipalities to treat sex-related businesses differently to other entertainment venues (Lewis 2000; Hanna 2005). Sides $(2006,375)$ accordingly suggests 'objective' decisions about the appropriate location for sex-related businesses are infused with contradictory understandings of sex districts as sites of 'perverse hedonism, female degradation, benign bacchanalianism, sexual liberation, contagion and violent crime'.

Although the US system of zoning sex-related businesses is most fully researched, related tactics of spatial governmentality are evident throughout the urban West (see Sullivan 1997; Lewis and Matika-Tyndale 2000; Hekma 2005). For instance, in England and Wales, while it is theoretically possible to influence the location of sex-related businesses through the planning process, the fact it is not distinctly defined in the Use Classes Order means municipally-operated systems of licensing are more significant. However, despite recent attempts to simplify the system under the 2003 Licensing Act, the situation remains complex, with sex cinemas, sex shops and 'sex encounter' businesses remaining under the remit of the 1982 Local Government Act but striptease and nude dancing venues licensed as premises providing public entertainment. In the case of the latter, applicants are legally required to state where 'entertainment or services of an adult or sexual nature are commonly 
provided' (DCMS 2003, 26), and, if licenses are awarded, the local authority is required to impose a strict exclusion of under-18s when such licensable activities are being conducted. Additionally, local authorities may also impose conditions on window displays, signage and opening hours (Goudie 1986). Consideration of the cumulative impacts of licensed premises in a given locale may also be a matter considered by licensing authorities, who are encouraged to view licensing as part of a 'holistic approach to the management of the evening and night-time economy in town and city centres' (DCMS 2003, 26). As such, licenses may be refused if the licensing authority perceives a venue will have 'negative impacts on members of the public living, working or engaged in normal activity in the area concerned', with concerns about proximity to places of worship, community facilities, schools, residences and/or other licensed premises often used to justify refusal of licenses. When combined with clauses in the 1982 Local Government Act stating 'the grant or renewal of a sex shop or sex encounter establishment license would be inappropriate having regard (i) to the character of the relevant locality or, (ii) the use to which any premises in the vicinity are put', this effectively allows local authorities to prevent sex-related businesses opening anywhere within their boundary should they deem there is no suitable locale available (Manchester 1986).

In sum, the licensing system in England and Wales works on the presumption licenses will be granted to sex-related businesses unless the local authority has specific concerns about crime, disorder and public nuisance (for an overview of the Scottish situation, see Adult Entertainment Working Group 2006). In practice, however, the willingness of different local authorities in England and Wales to grant licenses to sex-related premises has been highly variable, with some towns notably refusing to license lap-dancing clubs. Further, the types of conditions imposed on licensed premises also vary considerably, creating some interesting spatial anomalies. For instance, in the 1990s, Westminster City Council (who license premises in Soho and the West End of London) imposed a no-nudity condition on the licensed lap-dancing clubs within their boundaries (forcing dancers to wear approved gstrings), whereas neighbouring Camden allowed full nudity. This meant that clubs within a few hundred yards of one another operated according to very different conditions, and it was not until infamous club owner Peter Stringfellow appealed successfully against what he regarded as anti-competitive trading laws that Westminster City Council dropped its no- 
nudity condition (though it has retained a condition demanding a one-metre gap between performers and audience). On a national scale too, it is clear local authorities reach different conclusions about what is in need of a license. The retail chain Ann Summers, for example, sells lingerie and sex toys in its outlets, but because the latter do not constitute a 'significant proportion' of its stock, it is not regarded as subject to sex shop licensing conditions.

However, Bristol City Council beg to differ, making this the only one of Ann Summers' 116 UK stores which operates as a licensed sex shop.

As opposed to street prostitution, where the police are charged with enforcing national legislation, it is hence the discretionary and selective enforcement of planning and licensing guidelines by municipal governors and officials that has been the key influence on the location and form of sex-related businesses. Kohm and Selwood $(2004,52)$ consequently draw on Foucault to argue that municipal governments employ 'tactics rather than laws' to achieve a level of control over sex businesses. In this sense, municipal licensing can be viewed as just one governmental tactic used to manage adult entertainment, which the local state typically regards as a form of business in need of particular and special attention. Bought within the remit of legitimate commercial exchange, licensing allows the state to exercise some control over sex businesses, albeit this relies upon the cooperation of the private sector. As Valvadere (2003) writes in the context of alcohol licensing, imposing this form of self-regulation represents a fairly cheap means of controlling businesses potentially disruptive of morality and order; moreover - given it is about the regulation of premises, not the policing of individuals - it allows the state to sidestep questions of individual liberty and morality. Yet, as Valvadere $(2003,237)$ notes, licensing's tendency to 'externalise the state's duty to manage the risks or urban disorder by delegating it to a non-technical and non-expert personnel' (i.e. venue managers and door-staff) should not distract from the fact that licensing officers, committees and magistrates exercise considerable discretion in determining which businesses are appropriate in which spaces.

\section{FROM THE MARGINS TO THE CENTRE? EXPLAINING THE RISE OF 'ADULT ENTERTAINMENT'}


As the preceding discussion makes clear, notions of spatial exclusion appear especially pertinent in exploring the historical geographies of sex-related businesses. Naked or seminaked dancing, in particular, has rarely been regarded as obscene, yet has marked the threshold between what the state and law defines as harmless titillation and that which it considers morally corrupting. As such, it has been socially marginalised, its association with particular notions of sexual danger and impropriety often used to justify the distancing of naked dance venues from 'family' and mainstream urban entertainments. Lasker (2001) notes this segregation satisfies a number of purposes simultaneously, allowing those who want to avoid such venues to do so, while granting those who wish to visit them anonymity. Districts including Soho (London), die Wallen (Amsterdam), New Orleans' Bourbon Street, the Reeperbahn (Hamburg), Pigalle (Paris) and Kabikicho (Tokyo) have hence attracted and repelled different audiences over time by offering a cluster of sex-related businesses (Ashworth et al 1988); in most towns and cities, however, there is no 'red-light' district as such, and venues have characteristically been scattered across the less salubrious parts of the city. Liepe-Levinson $(2002,22)$ accordingly argues 'the sleazy nudie bar, hidden away in a municipal district of-ill repute' epitomizes both the 'cultural and geographical location' of adult entertainment in most cities (see also Lyons et al 2003).

The idea sex-related businesses are excluded to liminal urban spaces (or 'danger zones') is thus frequently noted in the literature, with commentators suggesting this mirrors the traditional social stigma associated with commercial sex (Adler 2004). Geographical debates concerning NIMBYism are certainly germane here given it is often middle-class residents and property groups who oppose the opening of sex-related businesses, projecting fears of bodily impurity and uncleanliness onto the customers of such venues (Greek and Thompson 1994). That said, recent years have witnessed major changes in the organisation, marketing and regulation of sex-related businesses (Bruckert and Dufresne 2002). Crucial here has been the diversification of commercial sex work, with demand for sexual services becoming evermore specialised, splintering along technological, spatial and social lines (Bernstein 2004). New forms of sexual commerce based on physical or virtual exchange have emerged, with spending on sexual services reaching extraordinary new levels. In short, the 'sex industry' has become an acknowledged growth sector in consumer-based societies (Weitzer 2005). For many commentators, the most crucial factor here is the 'mainstreaming' of many elements of 
the sex industry, evident in increasingly dense connections between sex-related businesses and businesses such as hotel and pub chains, satellite television companies and Internet providers (Chatterton and Hollands 2003; Bernstein 2004). Wonders and Michalowski (2002) suggest this is clearest in the major world cities which act as nodal points in the globalised economy, where sex-related businesses now feature extensively in the plethora of guidebooks, listing magazines and web sites designed to orientate tourists and business travellers alike. Yet beyond such metropolitan centres, the commercialisation of sex can also be registered in the increasing number of naked dancing venues, hostess bars and peep shows in smaller towns and cities, with nearly 4000 adult cabarets in the US alone - a figure that doubled between 1987 and 2003 (Egan 2003). Hausbeck and Brents (2002, 102) thus claim the proliferation of adult venues is one of the clearest manifestations of the transformation of the sex industries from a 'small, privately-owned, illegitimate and almost feudal set of businesses dependent on local sheriffs looking the other way' to a 'multi-billion dollar business dominated by corporations'.

While technological changes (not least mobile telephony and the Internet) are clearly implicated in the expansion of commercial sex, the rise of sex-related businesses can also be related to the decline of manufacturing economies and the rise of a more playful, consumerbased economy. In societies where more and more spaces are given over to consumption, and where affluent male consumers have become particular targets for retailers, businesses trading on the commodification of women's bodies have therefore taken on heightened significance (Attwood 2005). Liepe-Levinson (2002) argues that notions of sexual liberation may also be significant here, contributing to the representation of sex-related businesses as recreational settings, with a discourse of free sexual expression finding its corollary in the idea sex can be bought and sold like any other service. Bernstein (2004) persuasively develops this argument, suggesting the buying and selling of sexuality is now fundamentally dissociated from the idea of 'emotional' exchange, and hence is more easily incorporated within (male) understandings of legitimate consumption, 'play' and even work (see Connell 2001 on transnational business masculinities). As Bernstein $(2004,212)$ contends, this means the act of purchasing sexual services is increasingly situated in the context of 'a normalised field of commercial practices', with clients' search for erotic encounter only understandable in the 
context of tendencies towards 'plastic sexuality' (Giddens 1991) and the emancipation of eroticism from reproduction and 'love' (Bauman 1998).

Given the increasing dominance of this recreational notion of sexuality, sex-related businesses are now widely regarded as integral to urban economies, with the 'soaring demand for pornography, strip clubs, lap-dancing, escorts, and sex tours' seen to draw increasing numbers of affluent consumers towards cities (Bernstein 2001, 389). In the UK, for example, proponents argue sex-related business promotes both business and group tourism (especially 'stag' and 'hen' parties), with the three hundred or so venues in the UK conservatively estimated to contribute $£ 300$ million to the economy annually (Adult Entertainment Working Party 2006). The increased attention devoted by policy-makers to promoting the evening economy - a key 'driver' of the UK's post-industrial economy - is highly significant here (Chatterton and Hollands 2003). Imbued with a new-found respectability, sex-related business has been re-dubbed 'adult entertainment', and deemed compatible with the cosmopolitan and 'continental' ambience seen as essential in creating a sustainable 24-hour city economy (Measham 2004). With the fashionable and super-rich noted as frequent visitors to spaces of adult entertainment, it is perhaps unsurprising many urban politicans are upfront in their support for adult entertainment (see especially Sanchez 2003 on the politics of urban regeneration in Portland, US).

Yet there remain important local (and national) variations in the acceptability of adult entertainment (see, for example, Kulick 2005 on Swedish condemnation of the sex-industry, and Sharp 2003 on resistance in specific US cities). Indeed, the emergence of new spaces of sexual encounter can trigger moral approbation and anxiety in some instances, and remains associated with NIMBY-style campaigns of opposition (Manchester 1986; Bofffa et al 1994). The recent furore surrounding the granting of a license to a lap-dancing club in the shadow of Southwark Cathedral (South London) is a case in point, with London Mayor Ken Livingstone publicly adding his support to local clergy and community campaigners, arguing this 'very offensive eyesore' jeopardizes the ongoing rejuvenation of the area (cited in The Guardian April 6 2006). Likewise, community groups in Edinburgh's Tolcross district allege the area's six table-dancing clubs are turning the streets into a 'northern Faliraki' where groups of 'testosterone-pumped men' run amok on a Friday and Saturday night (The Scotsman 
July 5 2004, 6). As such, sex-related businesses continue to be regarded by some as promoting lewd and violent male behaviour (Bindel 2004), with new sites such as the topless carwash Babes and Bubbles and international chain of restaurants Hooters generating related anxieties about the putative 'democratisation of pornography' and rise of 'raunch' culture (Attwood 2005). Those who visit sex-related businesses continue to be vilified in some quarters, with the identification of clients as deviant and disordered a key motif in the oppositional rhetoric of those contesting he opening of sex-related businesses (Boffa et al 1994).

It is therefore dangerous to suggest a new mood of sexual permissiveness is leading to the acceptance of sex-related businesses in each and every locale. Indeed, the majority of municipal governments in the urban West continue to use by-laws, licensing and planning powers to manage sex-related businesses so as to assuage the concerns of local residents, retailers and landowners (Kelly and Cooper 2001). Contemporary studies of the licensing of sex-related businesses are few and far between (Gerard 1982; Manchester 1986; Kohm and Selwood 2004), but suggest that while there is now a presumption towards allowing sexrelated businesses to open, officials will consider factors such as the likely clientele for a premise, the good character of the owner/manager and the nature of the entertainment offered when deciding whether to grant a license. As such, systems of licensing may be framed so as to discourage certain types of adult entertainment occurring, often based on the assumption that owners will be unable to prevent criminal or 'deviant' behaviour occurring in premises where such entertainment is provided (Bernard et al 2003). Unlicensed or unregistered premises therefore exist in a zone of disreputability, and may ultimately be forced to close down. As Bernstein $(2001,410)$ perceptively observes, such attempts to eradicate the most problematic segments of the industry serve a dual purpose, effectively legitimising the 'unproblematic' parts that remain.

Here, it appears that useful connections might be forged with geographic debates surrounding the regulation of other leisure activities that provoke moral panic, such as gambling or the consumption of alcohol (see Marshall 1998; Valvadere, 2003; Measham 2004). The latter, for example, is currently deemed integral to the cultivation of creative, profitable night-time economies but continues to be associated with intoxicated violence, 
with distinctions thus made between 'horizontal' drinking and civilized café culture (one the one hand) and the spaces of 'vertical' drinking (on the other). The regulatory orientation towards café style (and possibly family-oriented) spaces of alcohol consumption is thus an oft-noted trend, with the general enthusiasm to construct vibrant and vital 24-hour cities accompanied by countervailing tendencies to 'rein in' sites promoting binge-drinking or excessive consumption (Talbot 2004; Chatterton and Hollands 2003; Dixon et al 2006). Hobbs et al $(2003,95)$ argue 'the marriage of leisure and commerce within after-dark postindustrial urban centres is a union consummated by de-regulatory pragmatism and ordained via implicit governmental sanction and an expectation of righteous consumption'. In other words, while policy-makers recognise spaces of alcohol consumption can contribute to a vibrant and pleasurable night-time economy, the liminal nature of such premises encourages the state and law to set limits on their operation lest their transgressive potential disorders the city at night. It is within the context of such contradictory tendencies towards regulation and deregulation that the contemporary geographies of sex-related businesses must be understood, with the state acknowledging the (lucrative) demand for adult entertainment, but clearly regarding some sex-related businesses more appropriate than others.

\section{URBAN GENTRIFICATION AND THE CORPORATISATION OF ADULT ENTERTAINMENT}

Though studies of the urban geographies of sex-related businesses are few in number, they overwhelmingly suggest strategies of licensing and zoning have enacted a form of 'prophylaxis' designed to spatially-delimit 'zones of debauchery' (Symanski 1981, 78). In so doing, the distance between adult entertainment and those affluent residents most likely to accuse adult entertainment of lowering the tone of their neighbourhood has been effectively maintained (Boffa et al 1994). The consequent exclusion of sex-related businesses from middle-class 'family' spaces hence contributed to their identification as respectable (and valuable) neighbourhoods. Turning this around, the implication is that the presence of sexrelated businesses in a locale has been read not just a symptom of disinvestment, but a sign that an area is ripe for reinvestment and repopulation (irrespective of the fact that an area 
may already have an established population). As such, developers have often represented sex businesses as obstacles needing to be removed before investment and 'improvement' could occur. This typically involves a series of moves where a boundary is drawn between good and bad property; in this equation, sex-related businesses are rarely depicted as embodying 'highest and best use' (Blomley 2004).

Developing these ideas on class, law and property, Papayanis (1999) has offered perhaps the most through-going attempt to situate the geographies of adult entertainment within the context of debates concerning the social production of space. In her account, amendments to New York's zoning laws introduced in the 1990s by Mayor Giuliani to disperse sexrelated businesses with the claimed intention of protecting vulnerable neighbourhoods were actually intended to assist the gentrification of areas 'blighted' by pornography (see LiepeLevinson 2002). Accordingly, Papayanis interprets New York's zoning as part of an attempt to displace adult businesses in the interests of corporate development, with the redevelopment of the $42^{\text {nd }}$ Street Precinct and Times Square highlighted as a particular instance where gentrification was reliant on the zoning-out of sex:

The antithesis of productive social space - the Times Square of recent memory was shunned by developers, the middle classes and mainstream retailers alike as a kind of no-man's land saturated, in the popular imagination, with sex, sleaze and criminality. As its down at heel charm and small-scale economic diversity gave way to Disneyland, we can see the extent to which representations of space have succeeded in domesticating those clandestine or underground manifestations associated with representational or lived space (Papayanis 1999, 351).

Despite mixed evidence that the presence of adult businesses actually impacted negatively on property values in the Times Square district (Insight Associates 1994), its subsequent

reinvention as the $42^{\text {nd }}$ Street Precinct Business Improvement District is often cited as a key milestone in New York's battle against X-rated businesses (Riechl 1999; Boyer 2001; LiepeLevinson 2002; Miller 2002). 
In accordance with the revanchist city politics that seeks to remove potential threats to property-fuelled gentrification (Smith 1996), it is thus possible to identify sex-related businesses as anathema to the cultivation of a leisured and profitable 'glamour zone' at the heart of Western cities. Indeed, examples not just from New York, but also Tokyo, Paris, and Amsterdam, suggest that there are many sex-related businesses regarded as incompatible with consumer-fuelled gentrification (see Brants 1998; Sugiayama 2002; Hubbard 2004). In central London, for example, Westminster City Council has been keen to promote a familyfriendly tourist experience, closing the hostess bars, 'clip joints' and sex cinemas that it felt created a bad impression for visitors (Hubbard 2004). However, the fact many forms of adult entertainment are now imbued with fashionability (if not respectability) implies councillors, residents and local property owners alike may be more sanguine about other sexrelated businesses, acknowledging their contribution to the vitality of the urban scene. Hence, while unlicensed 'girlie shows' and pub stripping are fast disappearing in London, licensed 'gentleman's clubs' proliferate (Clifton et al 2002).

Consequently, at the same moment the real estate companies, property developers and entertainment conglomerates keen to profit from the boom in the cultural economy identify some forms of commercial sex (especially prostitution) as an obstacle to urban gentrification (Kerkin 2004), they clearly regard others as entirely appropriate (Sanchez 2004). In particular, sex shop chains like Playboy and Hustler Hollywood are deemed to be sufficiently upmarket to be part and parcel of the gentrifying process, while lap-dancing chains such as Spearmint Rhino and For your Eyes Only are often represented as the antithesis of the 'bump and grind' strip club. Frank $(2003,65)$ argues such upscale clubs offer a 'fantasy of distinction', and provide a variety of services available to customers not traditionally associated with striptease clubs, such as fine-dining, charity events, conference rooms, and 'a distinguished atmosphere'. Significantly, the consumption of sexual services in such sites may be sanctioned by businesses as a legitimate form of corporate hospitality, with these clubs seen to provide a space where bonds between companies, employees and clients may be sutured in a male - and assuredly heterosexual - atmosphere (Holgersson and Svanstrom 2004). The idea that business travelers now expect to find such clubs within major world cities is often spoken of as justification for their existence (Wonders and Michalowski 2004). 
Coupled with the tendency for clients to contact sex workers via the Internet and mobile phone, contemporary urban landscapes of commercial sex are thus increasingly corporatised, with licensing authorities and planners typically deeming upscale clubs run by 'respectable' managers as acceptable leisure uses (Chatterton and Hollands 2003). In many instances, this means these clubs now occupy prime sites in entertainment and retail districts, with fewer found in the marginal areas traditionally associated with sex business (Jones et al 2003). Literatures on the sanitisation of consumer space and the recuperation of sexual Otherness hint at some important connections that might be made here between the corporatisation of sex work and gentrification agendas (see especially Binnie 1995; Hubbard 2004; Bassi 2006), but making generalisations about such processes is clearly difficult given processes of urban redevelopment need to be interpreted contingently. For such reasons, it is important that the type of analysis worked through in the context of New York (for example) is not extrapolated to other cities without due attention being paid to the contrary and complex forms of zoning and licensing existing for sex-related businesses. As such, while questions of capital and class may be crucial in some contexts, it appears vital to remain attuned to the way the location of sex-related businesses is shaped by cultural contingencies - not least the 'erotics of racism and misogyny' which may be differently insinuated in the making of sexual spaces (see Nast 2002).

\section{GENDER AND THE EXCEPTIONAL SPACES OF COMMERCIAL SEX}

As we have highlighted above, the idea that sex-related businesses now play a crucial role in attracting consumer and corporate investment to particular cities raises a number of important questions for geographers about the connections between the sex industry and the urban economy. Yet we would argue that one of the most pressing issues raised is the extent to which this process reflects a series of shifts in the gendering and sexualisation of urban space. Oddly, questions of gender are not at the forefront of many explorations of sexrelated businesses, perhaps because a number of these sites provide sexual entertainment for women as well as men (Clark 1985; Smith 2002). Some managers of adult entertainment venues make great play of their willingness to cater for female audiences, with one UK 
survey suggesting as many as one in five women who have been on a 'hen party' have visited sites offering male striptease (Mintel 2003). Further, in some cities there are businesses whose primary clientele is gay, lesbian or transsexual (Liepe-Levinson 2002; Uebel 2003). However, the vast majority of sites of adult entertainment are aimed squarely at (heterosexual) male consumers, and many continue to prohibit female customers from entering unless escorted by men, precluding women from becoming customers even if they wanted to (Frank 2003).

In this respect, many commentators allege that sex-related businesses reproduce hegemonic notions of masculinity and femininity. Liepe-Levinson (2002, 41), for instance, argues 'strip environments are spaces that have been made visible and hidden, extraordinary and naughty/deviant, for both men and women...in ways that reflect the social conditioning of gender norms'. Noting the preponderance of venues catering exclusively to men, LiepeLevinson argues that maintaining a separation between 'family-friendly' spaces and spaces of adult entertainment may help to construct a divide between good and bad femininity, reinforcing assumptions about the ability of women to navigate the sexual pleasures and dangers of the city. Similarly, Lasker $(2003,1181)$ contends that zoning protects 'good women with family values' from adult entertainment land uses by 'zoning such uses as far away from single-family, detached home neighbourhoods as possible, and into neighbourhoods that lower income women call home'. She also argues that, by claiming to protect women from danger, this zoning 'conceptually and semiologically separates women from experiencing parts of the city that remain open to exploration by men' (Lasker 2003, 1181). The implication here is that women can occupy such spaces only on men's terms and even then may be regarded as 'bad women' in need of constant surveillance and regulation. Adler (2004) makes a related argument in relation to the licensing conditions which insist on 'no touching' and minimum-clothing rules in erotic dancing venues, arguing city councils often identify nude dancing as a threat to 'public health' which leads to the 'spread of sexually transmitted diseases' (despite there being no sexual contact between strippers and patron). This is reiterated, she contends, in court hearings where the 'gyrating' female body is depicted as an 'infectious threat to the clean boundaries of the body of First Amendment law' (Adler 2004, 1130). Offering an interesting slant on the state and law's need to control sites of adult entertainment, Adler argues the regulation of sex premises can 
only be understood in the context of the 'highly charged terrain of female sexuality'.

Such perspectives suggest the spatial regulation of sex businesses is framed in terms of conventional stereotypes of male sexual activity and female passivity, something mirrored in the performances played out within such spaces:

In exotic dance clubs, women at work must act like women by embodying traditionally female behavior and roles as well as by dressing and behaving femininely. Because the central features of the organizational culture within exotic dance clubs are the commodification and commercialization of women's sexuality, the clubs are premised on the consumption of women's bodies and the presence of those bodies in hegemonic male fantasies. Thus, women work not only as women but as sexualized women (Trautner 2005, 772)

Miller (2002) thus argues the 'moral overhaul' of city centres, and the gentrification of adult entertainment, assuages many social anxieties about commercial sex but ultimately facilitates men's continuing access to women's bodies by making sex-businesses more acceptable. As has been noted in studies of male flaneurie and consumption, the female subject is always a surface of critical concern, with patriarchal practices of ordering urban space allowing men to position women as objects for their visual pleasure and consumption in a multiplicity of leisure spaces. In this regard, recent policy shifts encouraging upscale businesses cannot be read as entirely benevolent, despite the cited belief that such clubs offer better conditions for women workers (including adequate changing areas with private lavatories, heating and running water). For instance, accounts of the legalized brothels of Nevada (e.g. Brents and Hausbeck 2005) argue regulation and bureaucratisation may reduce the number of sexual attacks on women, but provides little freedom to women in terms of their working hours and conditions of employment. Studies of exotic dancing likewise suggest women working within licensed sex spaces are required to perform a type of emotional labour which ultimately 'erases their subjectivity' and self-worth (Wesley 2002; Bernard et al 2003; Egan 2005), even if some exotic dancers claim to find their work both liberating and well-paid (Hanna 2005). Anecdotal evidence also suggests that dancers in some upscale lap-dancing clubs (where they actually pay to dance) struggle to survive on tips, and may resort to 
prostitution to augment their meagre earnings. Forms of regulation may also be experienced as highly restrictive, with Bruckert and Dufresne (2002) noting proactive 'sting' operations have been increasingly been adopted by Canadian police to ensure dancers are not transgressing the prohibition of touching during dancing, despite dancers' claims that such bans seriously compromise their earning potential.

The implication here is the transformation of sex-related businesses into sites of 'adult entertainment' has not granted workers the forms of workplace legitimacy and recognition they have long argued for, with workers lacking even basic employment contracts in most cases. The often-parlous nature of employment in the adult entertainment sector is underlined by Sanchez $(2003 ; 2004)$ in her studies of Portland's sex industries, wherein she notes the tendency for those women employed within recognized and legal businesses to nonetheless find themselves denied the appellation of worker (in many instances, because they actually pay to participate in sexual commerce despite a significant proportion of their tips going to club owners). Suggesting that sex work is still not recognized as a form of labour, despite attempts at unionization, Sanchez argues those working in adult businesses may be 'less excluded' than street prostitutes, but remain economically exploited and legally subordinate to those labouring bodies whose disciplining remains the central focus of state activity. Arguing the social and symbolic construction of the sex worker as a figure of exclusion is a 'recalcitrant cultural ritual' that serves a broader purpose than 'any local contest of legality and land use can explain', Sanchez thus identifies zoning policies as tactics of spatial management which serve to produce 'enclosed spaces and zones of exclusion (camps) within the city and nomadic and anarchistic spaces outside where men can execute their own private sovereignty upon the bodies of prostitutes, through violence, rape, mutilation, and murder' (Sanchez 2004, 871-872).

Sanchez's characterization of sex workers as excluded and nomadic is interesting given it draws on the work of Giorgio Agamben, and particularly his notion of homo sacer - a figure who exists on the threshold of the sovereign state. Positioned beyond juridicial law, homo sacer is abandoned in spaces of exception (e.g. concentration camps, prisons) where he retains a connection with the sovereign state, included through exclusion. Much cited in recent geographical work, Agamben's attempt to locate subjects on a continuum between 
man and beast (with homo sacer on the threshold between, in a zone of indistinction) thus provides an opportunity to explore how those who exist in a state of exception are managed through particular spatial strategies. Writing on the fundamentally gendered construction of homo sacer, Mitchell $(2006,103)$ argues it is, however, vital to remember that modern homo sacer is 'always already a woman' (see also Pratt 2005). Arguing that certain women are just too different or discrepant to be 'folded into' the liberal project any longer, Mitchell alerts to a historically unprecedented abandonment of those regard as Other to the global white male. While much work has been conducted on those immigrant workers, refugees and asylum seekers who take on this mantle, and exist in a state of liminal drift, Mitchell's citation of Sanchez's work suggest the female sex worker is also subject to geographical abandonment, with her rights as a citizen curtailed through the complex enfolding of public and private gendered spaces. For instance, even when working in licensed public spaces, the female dancer typically has no rights as worker or performer, and can be cast aside by club owners on a whim.

Reading the spaces of adult entertainment as spaces of exception provides a sometimes disturbing take on the lack of rights and respects afforded to dancers and performers. However, generalizing about the legal abandonment of women who work in such spaces is difficult given international variations in the regulation of sex work, which does not always subject those working in sex businesses to the forms of surveillance and exceptionalism documented by Agamben (see Outshoorn 2004). Further, the idea that sex-related businesses, or the sex industry more generally, inherently reproduces male privilege has been challenged by accounts that highlight the agency of sex workers and exotic dancers (Law 1997; Liepe Levinson 2002; Hanna 2003) - some written by ex-dancers (Egan 2003). For instance, Bott's (2006) study of women dancers suggests that many discuss it as a means of self-realization and even as a way of seeking respectability (i.e. dissociation from pathologized version of working class femininity). Crucial here for many women is the idea that working in the 'respectable' adult entertainment sector distances them from the 'dirt' associated with prostitution. Likewise, many proclaim it allows them to self-express and celebrate their own femininity, and claim they remain in complete control of the audience, able to determine the parameters of the encounter between performer and dancer (and hence maximize the resulting economic rewards) (Hanna 2005). 
Identifying how sex workers and dancers are differently located in 'common-sense' but profoundly gendered hierarchies of political inclusion/exclusion must therefore be a chief goal for researchers of adult entertainment - not least given customers are often (stereotypically) imagined to be 'free-floating' international businessmen (see Mitchell 2006, 103). Central to such a project is the combination of qualitative and quantitative data to elicit the differential subjectivities and legalities played out in spaces of adult entertainment. Indeed, while some ethnographies of exotic dancing have detailed the encounter between client and worker (Frank 2003; Montemurro 2001) and the negotiation of a stigmatized or 'deviant' identity (Bernard et al 2003), much work remains centred on the dancer-worker rather than client-customer, and there remains a serious lack of research on how sites of adult entertainment are actually consumed (for a related argument, see Sanders 2004). As such, little has been said about the ways that adult entertainment has become integral to specific urban cultures and rituals of identification, such as forms of corporate entertainment (see Allison 1994; Holgersson and Svanstrom 2004), the 'stag-do' (Mintel 2003) or the 'lad's night out' (Chatterton and Hollands 2003; Nayek 2003). Ultimately, a more careful and rigorous exploration of the spaces of adult entertainment would not only help us appreciate the way these sites are woven into these leisure routines but also understand how the city itself is organized to facilitate variegated rituals of male identification (Attwood 2005).

\section{CONCLUSIONS}

Often taken as evidence for the rise of 'ranch culture' and 'porno-chic', adult entertainment in the form of sex shops, pole- and lap-dancing clubs, topless bars and burlesque revues is now more evident than ever before (Egan et al 2006). In this paper, we have contended that the increasing visibility of such venues at the heart of our cities is worthy of further investigation, not least because it challenges taken-for-granted assumptions that commercial sex is both socially and spatially marginalised. Indeed, the corporatisation and gentrification of sex businesses implies the boundary between 'transgressive' and 'normal' forms of heterosexuality has shifted decisively: those visiting adult entertainment venues are less likely to be stigmatised than was the case in the recent past, with the image of the sexually- 
inadequate and solitary customer largely eclipsed by that of the urbane, affluent consumer who is confident in his own sexuality and masculinity, and may use such sites for corporate or group entertainment (Erikson and Tewkesbury 2000; Frank 2003). Nonetheless, the development of adult entertainment venues remains contentious, and there remains significant conflict between those who regard adult entertainment as integral to the cultivation of a vibrant night-time economy, and those who feel it is incompatible with the creation of inclusive (and 'family') leisure spaces.

In this paper, we have hence argued that geographers need to devote more attention to the debates surrounding the place of adult entertainment in our town and cities. The fact that sex-related business - always integral to city economies - are now more visible, central and accepted in mainstream spaces of nightlife suggests there may be important connections to be made between contemporary consumer practices, sexual economies and urban gentrification processes. While the literature on the gay commercial scene (Binnie 1995; Brown 2001) offers some useful points of departure here, there may well be specific issues relating to dominantly-heterosexual adult entertainment venues which means the two cannot be easily conflated in theoretical or empirical terms. Considering how regulators and licensing bodies associate particular clienteles with particular types of venues may thus reveal why certain types of adult venue enjoy prominence, while others - such as sadomasochism clubs - remain residualised. Nascent debates in legal geography concerning property, propriety and citizenship are clearly relevant here given the regulation of adult entertainment involves value judgements being made about the types of premise that are appropriate in given locations (Blomley 2004). There are also, we suggest, important dimensions of adult entertainment that speak to debates in feminist and postcolonial geography; for example, the role of adult entertainment in normalising new forms of masculinity and femininity (Sanchez 2004); the exoticisation and racialisation of sexuality (Nast 2002), and the encouragement of sex-related tourism and migration (Wonders and Michalowski 2004).

Finally, however, we must concede that accounts emphasising the mainstreaming of adult entertainment may oversimplify the geographies of sex-related businesses. While pole dancing and lap dancing clubs may be increasingly found alongside the mainstream diversions (pubs, clubs, cinemas, theatres, casinos and restaurants) that characterise 
downtown entertainment districts, this does not mean that downmarket forms of adult entertainment have disappeared, with 'sleazy' and marginalised strip clubs continuing to represent the principal site of adult entertainment in many cities. In other instances, such clubs prosper as an alternative to upmarket clubs because they offer forms of dancing or sexual contact outlawed in licensed spaces. As such, it is impossible to generalise about the forms of adult entertainment one will encounter in Western cities, despite the increasingly global reach of the sex industry (Bernstein 2004). Indeed, the majority of accounts highlighting the proliferation of sex-related businesses emanate from the US and UK, and even there it is clear there are locally-significant variations in the way that the state and law regulates such venues (Sharp 2003). To imagine the type of processes encouraging the proliferation of adult venues in London or Las Vegas are the same as those encouraging them in, say, Belfast or Boston, is to gloss over important differences in local political culture. Moreover, moving beyond the US and UK, it is apparent that particular national traditions of sexual permissiveness, religious repression and political interventionism produce very different legal geographies of sex work, with adult entertainment taking distinctive forms in different cities (Allison 1994; Law 1997; Outshoorn 2004; Hekma 2005; Kulick 2005). The idea that sex-related businesses are becoming more mainstream in Western cities is hence a point of departure for further explorations of the geographies of adult entertainment rather than a definitive statement concerning the place of sex work in the urban West. Indeed, exploring the geographies of adult entertainment is an important activity not just because it sheds light on a multi-million pound industry, but because it allows us to draw conclusions about the type of sexual values and identities that adhere to spaces at different scales (i.e. from the micro-spaces of the body to the nation-state). As such, we conclude by suggesting there is always a need to locate spaces of adult entertainment within local, national and global hierarchies of acceptance and disavowal.

\section{REFERENCES}

Adler, A. 2004: Girls! Girls! Girls! The supreme court confronts the g-string New York University Law Review 80 (4) 1108-1155.

Adult Entertainment Working Group 2006: Adult Entertainment: report and recommendations. Edinburgh: Scottish executive. 
Agustín, L. 2005: The cultural study of commercial sex. Sexualities 8, 618-631.

Alamilla Boyd, N. 2003: Wide open town: a bistory of queer San Francisco to 1965 Berkeley: University of California Press.

Allison, A. 1994: Nightwork: sexuality, pleasure and corporate masculinity in a Tokyo hostess bar Chicago: Chicago University Press.

Ashworth, G., White, P. and Winchester, H.P.M. 1988: The red-light district in the West European city: a neglected aspect of the urban landscape. Geoforum 19, 201-212.

Assael, B. 2006: Art or Indecency? Tableaux Vivants on the London Stage and the Failure of Late Victorian Moral Reform Journal of British Studies 45, 744-758

Attwood, F. 2005: 'Tits and arse and fighting' Male heterosexuality in magazines for men. International Journal of Cultural Studies 8, 83-100.

Barcan, R. 2004: Nudity: a cultural anatomy London, Berg.

Bassi, C. 2006: Riding the dialectical wares of gay political economy: A story from Birmingham's commercial gay scene. Antipode 38, 213-35.

Bauman, Z. 1998: The postmodern uses of sex. Theory, Culture Society 15, 19-33.

Bernard, C., DeGabrielle, C., Cartier, L., Monk-Turner, E., Phill, C., Sherwood, J. and Tyree, T. 2003: Exotic dancers: gender differences in societal reaction, subcultural ties, and conventional support. Journal of Criminal Justice and Popular Culture 10, 1-11

Bernstein, E. 2001: The Meaning of the Purchase: Desire, Demand and the Commerce of Sex. Ethnography 2, 389-420

Bernstein, E. 2004: Desire, demand and the commerce in sex, in E Bernstein and Shaffner, L. (eds) Regulating Sex: The Regulation of Intimacy and Identity. New York, Routledge.

Bott, E. 2006: Pole position: migrant women producing Selves through lap-dancing work. Feminist Review 83, 23-41

Bindel, J. 2004: Profitable exploits: lap dancing in the UK. Child and Women Abuse Unit, London Metropolitan University.

Binnie, J. 1995: Trading Places: consumption, sexuality and the production of queer space, in Valentine, G. and Bell, D. (eds) Mapping Desire. London: Routledge

Blomley, N. 2004: Unsettling the city: urban land and the politics of property. London: Routledge.

Boffa, J., George, C. and Tsey, K. 1994: Sex, alcohol and violence: a communitycollaborative action against striptease shows. Australian Journal of Public Health 18, 45-59.

Boyer, C. 2001: Twice-Told Stories: The Double Erasure of Times Square, in Borden, I. Kerr, A., Rendell, J. and Pivaro. B. (eds) The Unknown City: Contesting Architecture and Social Space Cambridge, MA: The MIT Press.

Brants, C. 1998: The fine art of regulated tolerance: prostitution in Amsterdam. Journal of Law and Society 25, 621-635. 
Brents, B. and Hausbeck, K. 2005: Violence and Legalized Brothel Prostitution in Nevada: Examining Safety, Risk and Prostitution. Policy Journal of Interpersonal Violence 20, 270-295.

Brown, M. 2001: Closet spaces. London, Routledge.

Bruckert, C. and Dufresne, M. 2002: Reconfiguring the margins: tracing the regulatory context of Ottawa strip clubs Canadian Journal of Law and Society 17 69-87.

Chatterton, P. and Hollands, R. 2003: Urban nightscapes: youth cultures, pleasure spaces and corporate power London: Routledge.

Clark, R. 1985: Male Strippers: Ladies' Night at the Meat Market. Journal of Popular Culture 19, 51-56.

Clifton, L, Ainslie, R. and Cook, J. 2002: Baby oil and ice: striptease in East London: Do not press.

Connell, R.W. 2001: Masculinity politics on a world scale, in Whitehead, S.M. and Barrett, F.J. (eds) The Masculinities Reader Cambridge: Polity Press.

Cowen, D. 2003: From the American lebensraum to the American living room: class, sexuality, and the scaled production of 'domestic' intimacy Environment and Planning D - Society and Space 22, $755-771$.

DCMS 2003: Guidance issued under section 182 of the Licensing Act 2003. London: Department of Culture, Media and Sport.

Dixon, J.A., Levine, M. and McAuley, R. 2006: Locating impropriety: Street drinking and the ideological dilemma of public space. Political Psychology 27, 187-206

Egan, D. 2003: Eroticism, commodification and gender: Exploring exotic dance in the United States. Sexualities 6, 105-114.

Egan, D. 2005: Emotional Consumption: Mapping Love and Masochism in an Exotic Dance Club. Body and Society 11, $87-108$.

Egan D, Frank, K. and Johnson, L. 2006: Flesh for fantasy: producing and consuming exotic dance New York: Thunders Mouth Press.

Erikson, D.J. and Tewkesbury, R. 2000: The 'gentleman' in the club: a typology of strip club patrons Deviant Behavior 21, 271-293.

Fisher, R., Linz, D.G. and Paul, B. 2004: Examining the Link Between Sexual Entertainment and Sexual Aggression: Presence of Adult Businesses and the Prediction of Rape Rates in Florida. Paper presented to International Communication Association conference.

Frank, K. 2003: Just Trying to Relax: Masculinity, Masculinizing Practices, and Strip Club Regulars. The Journal of Sex Research 40, 61-75.

Frank, K. 2005: Exploring the motivations and fantasies of strip club customers in relation to legal regulations. Archives of Social Behavior 34, 487-505.

Friedman, A. 2000: Prurient Interests: Gender, Democracy, and Obscenity in New York City, 19091935 New York: Columbia University Press

Gerard, J.B. 1982: The local regulation of adult businesses. Deerfield: Illinois. 
Giddens, A. 1991: The constitution of society. Oxford: Blackwells.

Goudie, A. 1986: Local authority licensing of sex shops and sex cinemas London: Sweet and Maxwell.

Greek, C.E. and Thompson, W. 1992: Anti-pornography campaigns: saving the family in American and England. International Journal of Politics Culture and Society 5, 601-609.

Hanna, K. 2003: Exotic dance adult entertainment: ethnography challenges false mythology. City and Society 15, 165-193.

Hanna, K. 2005: Exotic Dance as Adult Entertainment: A Guide for Planners and Policy Makers. Journal of Planning Literature 20, 116-134.

Harcourt, C. and Donovan, B. 2005: The many faces of sex work. Sexual Transmission International 81, 201-206.

Hart, A. 1995: (Re)constructing a Spanish red-light district: prostitution, space and power. In D. Bell and G. Valentine, editors, Mapping desire: geographies of sexualities, London: Routledge, 214-229.

Hausbeck, K., and Brents, B. 2002: McDonaldization of the sex industry? The Business of sex. In Ritzer, G. (ed) McDonaldization: The reader, Thousand Oaks, CA: Pine Forge Press, 91 107.

Hekma, G. 2005: How libertine is the Netherlands? Exploring Contemporary Dutch Sexual Cultures. In Bernstein, E. and Schaffner, L. (eds), Regulating Sex: The Politics of Intimacy and Identity New York: Routledge.

Hobbs, D., Hadfield, P., Lister, S. and Winlow, S. 2003: Bouncers: Violence and Governance in the Night-time Economy, Oxford: Oxford University Press.

Holgersson, C. and Svanstrom, Y. 2004: Lagiga och oligaga affarer - om sexkopoch organizartioner research report no 20513, Stockholm: NorFa

Hubbard, P. 2000: Desire/disgust: mapping the moral contours of heterosexuality. Progress in Human Geography 24, 191-217

Hubbard, P. 2004: Revenge and injustice in the revanchist city: uncovering masculinist agendas. Antipode 36, 665-686.

Hudson, D.L. 1997: The Secondary Effects Doctrine: The Evisceration of First Amendment Freedoms. Washburn Law Journal 55, 37-54.

Hunter, I., Saunders, D. and Williamson, D. 1993: On pornography: literature, sexuality and obscenity law. London: St. Martins.

Jayne, M., Valentine, G. and Holloway, S. 2006: Drunk and disorderly. Progress in Human Geography 30, 451-468.

Jones, P., Shears, P. and Hillier, D. 2003: Retailing and the regulatory state: a case study of lap dancing clubs in the UK. International Journal of Retail \& Distribution Management 31, 214219.

Kelly, E.D. and Cooper, C. 2001: Everything You Always W anted to Know About Regulating Sex Businesses. Chicago: American Planning Association. 
Kerkin, K. 2003: Re-placing difference: planning and street sex work in a gentrifying area. Urban Policy and Research 21, 137-149.

Kohm, S.A. and Selwood, J. 2004: Sex Work and City Planning: Winnipeg's Red Light District Committee and the Regulation of Prostitution. Winnipeg: Institute of Urban Studies Working Paper.

Kulick, D. 2005: Four hundred Swedish perverts GLQ: a Journal of Lesbian and Gay Studies, 11 205-235.

Lasker, S. 1998: Sex and the city: zoning pornography peddlers and live nude shows. UCLA Law Review 49, 1139-1185,

Law, L. 1997: Dancing on the bar: sex, money and the uneasy politics of third space. In S. Pile and N. Thrift (eds) Geographies of Resistance. London: Routledge

Leonard, S. 2005, Pornography and obscenity, in Cocks, H.G. and Houlbrook, M. (eds) The modern history of sexuality London, Palgrave.

Lewis, J. 2000: Controlling lap dancing: Law, morality, and sex work, In Weitzer, R. (ed) Sex for sale. New York: Routledge

Lewis, J. and Matika-Tyndale, E. 2000: Licensing sex work: Public policy and women's lives. Canadian Public Policy / Analyse de Politiques, 26, 437-449.

Liepe-Levinson, K. 2002: Strip show: Performances of gender and desire. New York: Routledge.

Linz, D., Land, K., Williams, J. Ezell, M. and Paul, B. 2004: An Examination of the Assumption that Adult businesses are Associated with Crime in Surrounding Areas: A Secondary Effects Study in Charlotte, North Carolina Law and Society Review 69-104.

Lyons, D., Schoolmaster, A. and Bobbitt, D. 1999: Controlling the location of sexually oriented businesses. Applied Geographical Studies 3, 23-43.

Manchester, C. 1986: Sex shops and the law. Aldershot: Gower.

Marshall, D.C. 1998: Missing the Jackpot? The Proliferation of Gambling in Australia and its Effect on Local Communities Australian Geographical Studies 36 (3), 237-247.

Matthews, R. 2005: Policing prostitution ten years on. British Journal of Criminology 45, 1-20.

Measham, F. 2004: Play space: historical and socio-cultural reflection on drugs, licensed leisure locations, commercialization and control. Drug Policy 15, 337-345.

Miller, K. 2002: Condemning the public: design and New York's new 42nd Street. GeoJournal 58, 139-148.

Mintel Reports 2003: Stag and hen holidays UK. London: Mintel.

Mitchell, K 2006: Geographies of identity: the new exceptionalism. Progress in Human Geography 30, 95-106.

Montemurro, B. 2001: Strippers and screamers: The emergence of social control in a noninstitutionalized institution. Journal of Contemporary Ethnography 30, 275-304

Nast, H. 2002: Queer patriarchies, queer racisms, international Antipode 34 874-909.

Nayek, A. 2003: Last of the Real Geordies? White masculinities and the subcultural response to deindustrialisation. Environment and Planning D - Society and Space 21 7-25. 
Nead, L. 1997, Mapping the self: gender, space and modernity in mid-Victorian London Environment and Planning (A) 29 659-672

Outshoorn, J. 2004: The politics of prostitution. Cabridge: Cambridge University Press.

Papayanis, M. 2000: Sex and the revanchist city: zoning out pornography in New York Environment and Planning D - Society and Space 18, 341-354.

Paul, B., Linz, D. and Shafer, B.J. 2001: Government regulation of adult businesses through zoning and anti-nudity ordinances: Debunking the legal myth of negative secondary effects Communication Law and Policy 6, 355-391.

Pratt, G. 2005: Abandoned women and the spaces of exception Antipode 1053-1078.

Riechl, A. 1999: Reconstructing Times Square. Lawrence, University of Kansas Press.

Ross, B. and Greenwell, K. 2005 Spectacular striptease: performing the sexual and racial other in Vancouver 1945-1975 Journal of Women's History 17: 137-164.

Ryder , A. 2004: Adult entertainment spaces: between a rock and a hard place or going from strength to strength? Urban Studies 41, 1659-1686.

Sanchez, L. 2003: Sex and space in the global city. In Warren Perry, R. and Maurier, B. (eds) Globalization under construction, Minnesota: University of Minneapolis Press.

Sanchez, L. 2004: The global e-rotic subject, the ban and the prostitute free-zone. Environment and Planning D - Society and Space 22 (6) 861-883.

Sanders, T. 2004: Sex work: a risky business Culhompton, Willan.

Sharp, E.B. 2003: Local government and the politics of decency. Social Science Quarterly 84 (2) 262-276.

Sides, J. 2006: Excavating the Postwar sex district in San Francisco. Journal of Urban History $32,355-379$.

Sigel, L.Z. 2003: Governing Pleasures: Pornography and Social Change in England, 1815-1914 New Brunswick.

Smith, C. 2002: Shiny chests and heaving g-strings: a night out with the Chippendales Sexualities 5, 67-89.

Smith, N. 1996: The new urban frontier: gentrification and the revanchist city London: Routledge.

Sullivan, B. 1997: The Politics of Sex: Prostitution and Pornography in Australia since 1945. Cambridge: Cambridge University Press.

Sugiyama, K. 2002: The policing of covert sex workers in urban spaces in Toyama prefecture, Japan. Paper presented at the International Critical Geography Conference.

Symanski, R. 1981: The immoral landscape Toronto: Butterworths.

Talbot, D. 2004: Regulation and racial differentiation in the constructionof night -time economies: a London case study. Urban Studies 41, 887-901.

Tani, S. 2002: Whose Place is This Space? Life in the Street Prostitution Area of Helsinki, Finland. International Journal of Urban and Regional Research 26, 343-359 
Thomas, M.E. 2004: Pleasure and propriety: teen girls and the practice of straight space. Environment and Planning D - Society and Space 22, 773 - 789

Trautner, R. 2005: Doing Gender, Doing Class: The Performance of Sexuality in Exotic Dance Clubs. Gender and Society 19, 771-788.

Tucker, D. M. 1997: Preventing the secondary effects of adult entertainment establishments: Is zoning the solution? Journal of Land Use and Environmental Law, 12, 383-431.

Valverde, M. 2003: Police science, British style: pub licensing and knowledges of urban disorder. Economy and Society 32, 234-252.

Walkowitz, J.R. 2003: The vision of Salome: cosmopolitanism and erotic dancing in central London 1908-1918 The American Historical Review 108

Weitzer, R. 2005: New Directions in Research on Prostitution. Crime, Law, and Social Change 43, 29-45.

Wesley, J.K. 2002: Growing up sexualized. Issues of power and violence in the lives of female exotic dancers. Violence Against Women 8, 1182-120

Wonders, R. and Michalowski ,R. 2001: Bodies, Borders, and Sex Tourism in a Globalized World: A Tale of Two Cities - Amsterdam and Havana. Social Problems 48, 545571

Zook, M.A. 2003: Underground globalization: Mapping the space of flows of the internet adult industry. Environment and Planning A 35, 1261-1286. 